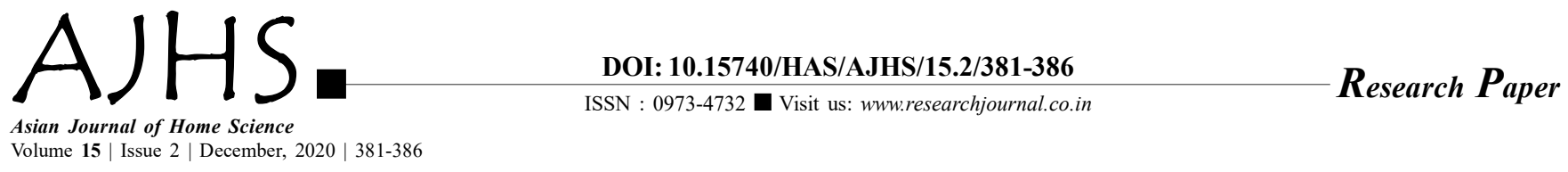

\title{
Selfie taking behaviour of college students
}

\section{Pallavi and Tulika Borah}

Received: 09.10.2020; Revised: 09.11.2020; Accepted: 26.11.2020

See end of the paper for authors' affiliations

\section{Pallavi}

Department Human

Development and Family

Studies, Assam Agricultural

University, Jorhat (Assam) India

Email : brar.pallavi1996@gmail.

com
ABSTRACT : The current study was undertaking with the aim of Selfie taking behaviour of college students. Yamane's formula used to calculate sample. In the current study total 203 respondents (undergraduate students) were selected randomly from two colleges of Assam Agricultural University, Jorhat. The data was analyzed using statistical methods in MS excel and SPSS. The results from the present study showed that majority of respondents $(61 \%)$ were taking Selfies occasionally, 62.56 per cent respondents took 1-3 numbers of Selfies on an average day and more numbers of the respondent (76.84\%) spent less than 15 minutes per day on taking Selfies. It may be because they were not easily satisfied with their self portrait. Respondents preferred to take Selfies at evening time, majority of the respondents preferred to take Selfies with their friends than others. Some of them like to take head/ face type of Selfies, and preferred different and attractive places. More number of respondents uploads their Selfies on whatsapp after editing and feels negative when the received negative comments on their portrait. A few of them felt upset when they saw negative comments on their Selfie and some respondents never untagged themselves in group Selfies if not looking good.

KEY WORDS: College students, Selfie, Selfie taking behaviour, Social media, Technology

- HOW TO CITE THIS PAPER : Pallavi and Borah, Tulika (2020). Selfie taking behaviour of college students. Asian J. Home Sci., 15 (2) : 381-386, DOI: 10.15740/HAS/AJHS/15.2/381-386. Copyright@, 2020: Hind Agri-Horticultural Society. 